\title{
Solid Waste Management-Survey in Mumbai Region
}

\author{
Karan V Jagasia and Pooja V Jagasia* \\ VES college of Arts, India
}

Submission: July 24, 2017; Published: August 16, 2017

*Corresponding author: Pooja V Jagasia, Associate professor, VES college of Arts, Science and Commerce, India, Email: pooja.jagasia@ves.ac.in

\begin{abstract}
The technique for squander transfer in antiquated urban communities was extremely unrefined as it was tossed on roads or on the open pits outside the urban communities. Alongside time, endeavors were made to discard the loss from urban areas since they cause strong waste contamination. Strong squanders are danger as it unfavorably influences both biotic and in addition abiotic segments of the earth. Up to this point, such wastes are arranged outside the city or town restrict where they are singed or compacted. Present day techniques for transfer, for example, cremation and improvement of sterile landfills and so on are utilized to take care of the issue. Dumping and consuming waste is not adequate practice from condition and wellbeing point of view. The transfer of strong waste ought to be a piece of a coordinated waste administration design. This paper will toss some light a few measures of by what method would solid be able to squander contamination can be lessened or controlled.
\end{abstract}

Keywords: Solid waste contamination; Management; Mumbai region; Centralized disposal; Land requirement

\section{Introduction}

India is swiftly shifting from agricultural-based country to industrial and services-oriented nation. About $31.2 \%$ population is now living in urban areas. Solid waste is the unwanted or useless solid materials generated from human activities in residential, industrial or commercial areas. Municipal solid waste management (MSWM), a basic component towards economical metropolitan improvement, contains isolation, stockpiling, accumulation, movement, convey age, handling, and transfer of strong waste to limit its antagonistic effect on condition. Unmanaged MSW turns into a factor for proliferation of incalculable afflictions. In the developed countries, solid waste management (SWM) belongs to prominent thrust areas for pursuing research and economic and technological advancements have initiated responsiveness of stakeholders towards it. High populace development rates, quickly fluctuating waste portrayal and era designs, developing urbanization and industrialization in creating nations are the essential purposes behind focusing towards MSWM as more regions is required to oblige squander. One of the significant problems in urban India is almost no segregation of MSW and disposal of construction and demolition debris (C\&D), plastic wastes, commercial and industrial refuses, and e-waste [1].

\section{Literature Survey}

Citizens in Mumbai have spent over Rs 13,000 crore towards cleanliness over the previous decade. In any case, the city has a modest $140^{\text {th }}$ rank to appear for this gigantic spending. Of the 9,400 tons of civil strong waste produced in Mumbai every day, the Deonar dumping ground, which has been gazing at conclusion since 2011, gets 3,500 tons and Mulund dumping ground 2,200 tons. Neither of these dumping grounds as of now being used have a waste handling unit, and generally un segregated and untreated junk is just dumped there, and the trash bursting into flames due to the gasses shaped are normal [2].

Table 1: landfill locales in the Mumbai district, whose normal life expectancy stays just 2-5 years.

\begin{tabular}{|c|c|c|c|c|}
\hline S. No. & $\begin{array}{c}\text { Location of Disposal } \\
\text { Waste }\end{array}$ & Site Area (Ha) & $\begin{array}{c}\text { Area Available for } \\
\text { Dumping }\end{array}$ & $\begin{array}{c}\text { Waste Received } \\
\text { (Tonnes/Day) }\end{array}$ \\
\hline 1 & Deonar & 131.12 & 116 & 4000 \\
\hline 2 & Gorai & 25 & 18.45 & 1,200 \\
\hline 3 & Mulund & 24 & 16.6 & 600 \\
\hline
\end{tabular}




\section{Recent Advances in Petrochemical Science}

In metro urban communities in India, an individual creates a normal of $0.8 \mathrm{~kg} / \mathrm{squander} /$ individual day by day. The aggregate municipal strong waste (MSW) produced in urban India has been assessed at 68.8 million tons for each year (TPY) (0.573 million metric tons for each day (MMT/d) in the year 2008). The normal gathering productivity of MSW ranges from $22 \%$ to $60 \%$. MSW ordinarily contains $51 \%$ natural waste, $17 \%$ recyclables, $11 \%$ risky and $21 \%$ latent waste. Be that as it may, around $40 \%$ of all MSW is not gathered at all and consequently lies littered in the city/town and discovers its approach to adjacent depletes and water bodies, causing stifling and also contamination of surface water. Un segregated waste gathering and transportation prompts dumping in the open, which creates leach ate and vaporous outflows other than causing annoyance in the surrounding condition (Table 1). Leach ate pollutes the groundwater and also surface water in the region and vaporous emanations add to a worldwide temperature alteration [3].

\section{Methods of Disposal}

\section{Centralized disposal}

Numerous nearby bodies achieve the decentralized gathering system by group canisters. In any case, there is adding up to carelessness about the transfer through decentralized units. Transfer is still done in unified framework. This is basic situation in metro urban communities of Maharashtra. Like in Mumbai, by and by there are three dumping grounds Deonar, Mulund and Gorai. Deonar is the biggest and the most seasoned dumping ground of Mumbai working since 1927. Mulund dumping ground is working since 1968 while Gorai is one of the littlest dumpsite of Mumbai Operating since 1972.

\section{Land requirement}

The fundamental imperative for the successful execution of MSW Rules and setting up of waste handling office for nearby bodies is non-accessibility of reasonable land. In a perfect world dumping sites ought to be situated at where there is, more often than not, no human populace or at a protected separation from all human settlement. Be that as it may, the expansion in the number of inhabitants in the city has constrained individuals to settle close to the dumping grounds. This prompts issues like individuals living in unfortunate conditions and challenging for the conclusion of the dumping grounds, as dumping causes wellbeing dangers for the general population in the vicinity. Increasing populace creates vast measure of waste, which requires the huge fix of land for its appropriate transfer. Be that as it may, with expanding urbanization, arrive accessible for dumping and making of landfill destinations for transfer of waste is getting to be noticeably troublesome particularly for metro cities. For case there are just 3 landfill locales in the Mumbai district, whose normal life expectancy stays just 2-5 years [4].

\section{Conclusion}

From the above investigation it is presumed that it is the huge need of present circumstances to get free from strong waste contamination. It can be controlled successfully through strong waste administration. As it is a troublesome undertaking, its principle destinations are to decrease the hurtful impacts and discover courses for their usage. Strong waste is hurtful for the earth whether it exists in strong, fluid or vaporous shape. Strong waste contamination is caused essentially through urbanization and through modern waste. It causes different sicknesses in human as bacillary loose bowels, the runs and amoebic diarrhea, torment, salmonellosis, trichinosis, endemic typhus, cholera, jaundice, hepatitis, gastro enteric ailments. Thus, administration of strong waste is extremely basic, it helps in decreasing strong waste contamination and makes contamination free and clean condition. Different strategies are rehearsed to control strong waste contamination as fertilizing the soil, reusing, cremation, pyrolysis, transfer, landfills. In any case, the proposed ones are unified transfer and land necessity. Subsequently, strong waste administration lessens or controls the strong waste contamination and its dangerous impacts.

\section{References}

1. Rajkumar J, Sirajuddin A (2016) Status and challenges of municipal solid waste management in India: A review. Cogent Environmental Science 2: 1-18.

2. http://indianexpress.com/article/cities/mumbai/dirty-mumbai6400-tonnes-of-solid-waste-40-pc-sewage-go-untreated/

3. http://www.indiawaterportal.org/topics/solid-waste

4. https://www.scribd.com/doc/1025767.80/EVS-Solid-WasteManagement-Mumbai

\section{Your next submission with Juniper Publishers} will reach you the below assets

- Quality Editorial service

- Swift Peer Review

- Reprints availability

- E-prints Service

- Manuscript Podcast for convenient understanding

- Global attainment for your research

- Manuscript accessibility in different formats

( Pdf, E-pub, Full Text, Audio)

- Unceasing customer service

Track the below URL for one-step submission https://juniperpublishers.com/online-submission.php 